\title{
Guideline
}

\section{Guideline for Treating Hepatitis B Virus Infection in Bangladesh}

\author{
Salimur Rahman ${ }^{1}$, Mamun-Al-Mahtab ${ }^{1}$, Md. Fazal Karim² \\ ${ }^{1,2}$ Department of Hepatology, ${ }^{1}$ Bangabandhu Sheikh Mujib Medical University, ${ }^{2}$ Dhaka Medical College \\ *Correspondence to
}

Viral Hepatitis Foundation Bangladesh, Suite \# 6 ( $2^{\text {nd }}$ floor $)$, Banani Super Market, Kemal Attaturk Avenue, Banani, Dhaka, Bangladesh, Tel: +880-2-8821989, Mob: +880-1552360067, Fax:+880-2-8826840, Email: hbd@dhaka.net

\section{Background}

Over 350 million people worldwide are infected with Hepatitis $\mathrm{B}$ virus (HBV) and globally around 1 million die due to consequences of this infection anually ${ }^{1}$. Bangladesh belongs to the intermediate prevalence region for HBV infection. Here the lifetime risk of acquiring HBV is between $20-60 \%{ }^{2}$. Studies from our as well as other groups have shown that HBV is responsible for $31.25 \%$ cases of acute hepatitis ${ }^{3}, 76.3 \%$ cases of chronic hepatitis ${ }^{4}, 61.15 \%$ cases of cirrhosis of liver ${ }^{5}$ and $33.3 \%$ cases of hepatocellular carcinoma $(\mathrm{HCC})^{6}$ in Bangladesh.

There is high prevalence of $\mathrm{HBeAg}$ negative $\mathrm{CHB}$ in our population. In our series we found $48.7 \% \mathrm{CHB}$ patients positive for $\mathrm{HBeAg}$, while the rest $51.3 \%$ tested negative ${ }^{7}$.

We have also observed that the most prevalent HBV genotype in Bangladesh is D (49\%) followed by C (38\%). In our patients with genotype $\mathrm{C}$, we found more often serum ALT and AST elevation than those with genotype D. Also, HBV DNA level is high in patients with genotype C (88\%) compared to genotype D (32\%). Histologic activity index (HAI) tends to be higher in patients with genotype $\mathrm{C}$ infection ${ }^{8}$. Since specialist healthcare to chronic HBV infected individuals in Bangladesh is delivered primarily by Internists, the aim of this guideline is to offer to them scientific approach in handling such patients in an easily understandable way that can be readily applied.

\section{Chronic inactive HBsAg carrier state}

Persistence of HBsAg in blood for more than 6 months is termed as chronic hepatitis B. HBeAg negative HBV infection may imply chronic inactive carrier state characterized by HBV DNA < 104 copies/ml and normal or near normal hepatic histopathology. In carriers, sero-conversion of $\mathrm{HBeAg}$ to anti-HBe generally implies reduction of viral activity and improvement in biochemical and histologic parameters.

\section{HBeAg negative CHB}

However the inactive carrier state must be differentiated form chronic hepatitis by mutant variety of HBV resulting from mutation in pre-core or core promoter region of the viral genome giving rise to $\mathrm{HBe} \mathrm{Ag}$ negative $\mathrm{CHB}$.

Besides $\mathrm{HBeAg}$ sero-conversion does not necessarily mean complete cessation of viral replication. It has been observed that over an 8 year follow up period, in a study population of 283 patients, $33 \%$ had ALT and HBV DNA elevation and $8 \%$ progressed to cirrhosis of liver ${ }^{9}$.

The biologic role of $\mathrm{HBeAg}$ in the replication of $\mathrm{HBV}$ is uncertain. Expression of $\mathrm{HBeAg}$ is not essential for viral replication in humans or in animal models. It has been suggested that $\mathrm{HBeAg}$ acts as a tolerogen or as a target for immune response. In addition $\mathrm{HBeAg}$ appears to modulate the host immune response.

In one of our studies where we recruited $80 \mathrm{CHB}$ patients, we found that $7.69 \%$ patients with $\mathrm{HBeAg}$ positive $\mathrm{CHB}$ had minimal chronic hepatitis, $69.23 \%$ had mild chronic hepatitis, $19.23 \%$ had moderate chronic hepatitis, while severe chronic hepatitis was seen in 3.85\%. In case of $\mathrm{HBeAg}$ negative $\mathrm{CHB}$, these figures were $10.71 \%, 53.57 \%, 25 \%$ and $10.71 \%$ respectively ${ }^{10}$. Later we studied a larger sample size and compared not only hepatic necro-inflammation, but also fibrosis between $\mathrm{HBeAg}$ positive and negative CHB patients. This study included 155 patients, 102 $\mathrm{HBeAg}$ positive and the rest 55 negative for $\mathrm{HBeAg}$. It was observed that $20.8 \%$ patients with $\mathrm{HBeAg}$ negative $\mathrm{CHB}$ had moderate to severe chronic hepatitis $(\mathrm{CH})$. In contrast, moderate to severe $\mathrm{CH}$ was seen in $18.6 \%$ patients with $\mathrm{HBeAg}$ positive CHB. Significant hepatic fibrosis (i.e. HAI-F score $>3$ ) was also more frequent in the HBeAg negative CHB group. $28.3 \%$ patients in this group had significant hepatic fibrosis as opposed to $19.6 \%$ patients with $\mathrm{HBeAg}$ positive CHB. In both these studies, we observed that patients with $\mathrm{HBeAg}$ negative $\mathrm{CHB}$ tend to develop more severe hepatic histologic involvement compared to their $\mathrm{HBeAg}$ positive counterparts ${ }^{11}$. In one of our more re- 
cent works, we studied $42 \mathrm{HBeAg}$ negative $\mathrm{CHB}$ patients with very low HBV DNA count (i.e. $<105$ copies/ml) only to discover that even in them, $26.2 \%$ patients had significant hepatic necro-inflammation (i.e. HAI-NI score 4-8) while significant fibrosis was seen in $19 \%$ patients $^{12}$. Similar experience is also shared by studies from Korea ${ }^{13}$, Turkey ${ }^{14}$, Egypt $^{6}$, Greece ${ }^{15}$, China ${ }^{16}$ and India ${ }^{17,18,19}$.

\section{Management of $\mathrm{HBeAg}$ negative $\mathrm{CHB}$}

It is very important to distinguish chronic inactive $\mathrm{HBsAg}$ carriers from $\mathrm{HBeAg}$ negative $\mathrm{CHB}$, as the later group has the potential of developing marked viral reactivation and has less chance of response to anti-viral medications ${ }^{20}$. A recent paper from Taiwan reports that the cumulative probability of hepatitis relapse in HBsAg carriers is $26.9 \%$ in males and $12.5 \%$ for females over a 20 year follow up period. Moreover $1.14 \%$ patients included in the study progressed to cirrhoisis per annum. The sample size in this study was $1241^{21}$.

Definitive diagnosis of pre-core mutation involves sequencing of viral genome20. However this is more of a research toll with practically no implication in the clinical setting. In an inactive carrier, ALT usually remains normal on serial monitoring with undetectable to low levels (i.e. $<105$ copies/ml) of HBV DNA. However the same may also occur in a patient with $\mathrm{HBeAg}$ negative CHB. HBV DNA is also not a very useful indicator as a Chinese study, involving 165 patients, reported that a single HBV DNA measurement misdiagnoses $45 \% \mathrm{HBeAg}$ negative $\mathrm{CHB}$ as chronic inactive HBsAg carriers. The study further revealed that even HBV DNA measurement on three separate occasions also misdiagnoses $30 \%$ cases $^{22}$. Besides a study of 196 CHB patients revealed that $10.5 \% \mathrm{HBeAg}$ negative CHB patients had HBV DNA $<30,000$ copies $/ \mathrm{ml}^{23}$.

The only way to distinguish between these two entities in a clinical set up is therefore performing a liver biopsy ${ }^{24}$.

The goal of treatment of any CHB patient is to prevent the development of cirrhosis, hepatic failure and hepato-cellular carcinoma (HCC). In $\mathrm{HBeAg}$ negative $\mathrm{CHB}$, response to treatment is said to have been obtained when one becomes negative for HBV DNA by PCR along with normalization of ALT and sero-conversion to anti-HBe. The problem however is that many $\mathrm{HBeAg}$ negative $\mathrm{CHB}$ patients test positive for anti-HBe at baseline and have persistently normal or near normal ALT. Moreover there is high incidence of relapse in this group of patients, even after HBV DNA becomes undetectable by PCR with treatment, the reason why initiating as well as determining the end- point of treatment in this group remains extremely difficult. The American Association for the Study of the Liver (AASLD) in it's recent CHB guideline advocates treatment of $\mathrm{HBeAg}$ negative $\mathrm{CHB}$ patients till $\mathrm{HBsAg}$ becomes undetectable ${ }^{25}$. This is an approach that is perhaps not too appropriate in the Asian setting. The reason for saying so is multifold including lack of trained specialists, poor socioeconomic condition, lack of patient awareness, poor follow up, high cost of drugs etc. This means that there will be high risk of introducing mutant HBV strains. However a better answer to this question is not yet known.

Besides all oral anti-virals currently approved for CHB treatment are also associated with variable risk of inducing viral resistance on long-term use. This risk is highest with lamivudine (LAM) and minimal with entecavir (ETV).

Emergence of HBV mutant can lead to negotiation of initial treatment. Patients are also at increased risk of developing hepatitis flares and decompensation. Such mutation is initially characterized by viral breakthrough, where there is a $>10$ log rise in HBV DNA. Viral breakthrough precedes biochemical breakthrough by months. In the later, there is rise in serum ALT. Such patients also develop cross-resistance to other anti-virals, like patients resistant to LAM will have cross-resistance to talbivudine (LdT) and vice-versa.

Interferon- $\alpha$ (IFN) for 48 weeks is associated with 38-90\% response as opposed to $0-39 \%$ response in controls ${ }^{26}$, however approximately $50 \%$ responders relapse post-treatment, some as late as up to 5 years later ${ }^{27}$. The sustained response my however be increased with prolonged treatment ${ }^{28}$. Besides $30-40 \%$ of these relapsers show sustained response following a second course of IFN- $\alpha^{29}$. Pegylated IFN for 48 weeks yields better results and the viral suppression is also better if LAM is added to pegylated IFN, however the sustained virologic response does not improve with this combination $^{30}$.

LAM is a nucleoside analog that yields $60-70 \%$ HBV DNA negativity at 1 year in $\mathrm{HBeAg}$ negative $\mathrm{CHB}^{31}$, but $90 \%$ of these responders unfortunately relapse post-treatment 30 . With longer duration of treatment, the response progressively reduces to $73 \%$ at 1 year and $34 \%$ at 2 years due to emergence of LAM resistant strains, usually YMDD mu$\operatorname{tants}^{32}$, where addition of adefovir (ADV) is usually effective.

ADV on the other hand is a nucleotide analog that leads to HBV DNA negativity in 64\% $\mathrm{HBeAg}$ negative CHB patients at 1 year of treatment ${ }^{33}$. ADV is a weaker drug compared to LAM and is unlikely to yield impressive results if 
the initial HBV DNA load is high. However in HBeAg negative CHB patients with low HBV DNA load at baseline, ADV may be a useful first-line option, as it is associated with much lower resistance rate compared to LAM. Addition of ADV to LAM benefits LAM-resistant CHB patients and vise versa, although the later is much less common.

The drug that is of much discussion these days is a carbocyclic analog called entecavir (ETV). It is much superior to LAM or ADV and is effective in LAM-resistant cases ${ }^{31}$. At 48 weeks, ETV yields HBV DNA negativity in $90 \%$ HBeAg negative CHB patients, compared to $78 \%$ with $\mathrm{LAM}^{29}$.

Telbivudine (LdT), a L-nucleoside analog, is a newer addition to growing list of oral anti-virals for CHB and at 1 and 2 years shows much better response to LAM in HBeAg negative $\mathrm{CHB}^{34}$. However these relatively newer drugs like ETV or LdT are yet to be time tested for long-term outcome.

Patients with $\mathrm{HBeAg}$ negative CHB must therefore be managed judiciously and in certain situations kept under close follow-up instead of rushing to treatment. However this does not mean advocating adoption of a too conservative approach, allowing many to proceed to irreversible and progressive liver disease (figure 1).

\section{Recommendation}

We would opt for treating HBeAg negative CHB patients with elevated ALT more times above baseline. However per-cutaneous liver biopsies should be performed routinely in them if HBV DNA is positive by PCR irrespective of the viral load and/or normal ALT level. The reason being that the definition of chronic inactive HBsAg carrier is not satisfied unless the liver histology is shown to be normal or near normal ${ }^{22}$.

We also recommend treating these patients if there is significant hepatic necro-inflammation (i.e. HAI-NI >3) and/or significant hepatic fibrosis (i.e. HAI-F>3). Else we recommend following up the patients with regular, periodic ALT estimation and treat when ALT shows a rising trend.

\section{Management of $\mathrm{HBeAg}$ positive CHB}

Treatment of wild type or $\mathrm{HBeAg}$ positive $\mathrm{CHB}$ is much more straight forward compared to $\mathrm{HBeAg}$ negative $\mathrm{CHB}$. Viral resistance is the main drawback of long-term antiviral therapy. Lamivudine monotherapy is associated with higher resistance (year 1, 10-27\%; year 2, 37-48\%; year 4, 60-
$65 \%$ ) than adefovir (year 1, 0\%; year 2, 3\%; year 5, 29\%) or telbivudine (year 1, 3-4\%; year 2, 9-22\%). Entecavir resistance is rare in naive individuals (year $4,<1 \%$ ), but increases over time in lamivudine-resistant patients (year 4, $43 \%)^{35}$.

Antiviral resistance and poor adherence are the most important factors in treatment failure of hepatitis B. On-treatment monitoring strategies to define early virologic responses that might be predictive of better outcomes and a reduced risk of viral resistance were proposed for further study. This treatment plan, labeled the roadmap concept, recommends monitoring of serum HBV DNA levels to identify outcomes of therapy. Primary treatment failure was defined as a reduction of serum HBV DNA levels by $<1$ $\log 10 \mathrm{IU} / \mathrm{mL}$ from baseline at week 12 . Measurement of the HBV DNA level at week 24 was considered essential to characterize virologic responses as complete, partial, or inadequate. Complete virologic response was defined as negative HBV DNA by a sensitive assay $(<60 \mathrm{IU} / \mathrm{mL}$ or $<300$ copies/mL); partial virologic response was defined as HBV DNA levels less than $2000 \mathrm{IU} / \mathrm{mL}$ (4 $\log 10$ copies $/ \mathrm{mL}$ ), and inadequate virologic response was defined as HBV DNA levels of $2000 \mathrm{IU} / \mathrm{mL}$ or greater $(4 \log 10 \text { copies } / \mathrm{mL})^{36}$.

\section{Recommendation}

We would opt for treating HBeAg positive CHB patients with elevated ALT more times above baseline. However per-cutaneous liver biopsies should be performed routinely in them if HBV DNA is positive by PCR irrespective of the viral load and/or normal ALT level. The reason being that a percentage of these patients show mild to severe chronic hepatitis on hepatic histology.

We also recommend treating these patients if there is significant hepatic necro-inflammation (i.e. HAI-NI > 3) and/or significant hepatic fibrosis (i.e. HAI-F >3). Else we recommend following up the patients with regular, periodic ALT estimation and treat when ALT shows a rising trend (figure 2).

\section{Recommendation for children, pregnant} women and cirrhotics

The recommendation for treating these groups is in line with that of HBeAg negative and positive CHB respectively with some special points to note.

In children, the response is poor with any anti-viral and hence treatment should be initiated with care. Some groups including our group recommend treating these patients with sequential combination of lamivudine and interferon, based 
on encouraging outcome in limited number of patients ${ }^{37}$, but there is not enough data at the moment to recommend this treatment.

In case of cirrhotics all oral anti-virals are safe; however injectable anti-virals are contraindicated in those with decompensated cirrhosis as this will lead to hepatic failure. However in decompensated cirrhotics, combination treatment with lmivudine and adef ovir may be given considering the fact that this group of patients will require long term treatment and perhaps life long. However renal function should be monitored.

We recommend treatment with lamivudine (pregnancy category $B$ ) in the third trimester of pregnancy in both $\mathrm{HBeAg}$ negative and positive $C H B$, if they fulfill treatment criteria. This is likely to reduce the risk of vertical HBV transmission significantly ${ }^{38,39}$.

\section{Recommendation for vaccination}

1. First degree relatives and house-hold contacts of HBsAg positive individuals.

2. All newborns born to HBsAg positive mothers. They should receive HBV immunoglobulin in addition routine vaccination.

3. Injectable drug abusers.

4. All patients with congenital haemolytic anaemia and on renal dialysis.

5. All healthcare personnel.

\section{References}

1. Mast EE, Alter MJ, Margolis HS. Strategies to prevent and control hepatitis B and C virus infections: A global perspective. Vaccine 1999; 26; 17 (13-14): 1730-3.

2. Tibbs CJ, Smith HM. Clinicians Guide to Viral Hepatitis. 1st Edition 2001, Arnold.

3. Mahtab MA, Rahman S, Khan M, Karim MF. Etiologic fraction of hospital-admitted acute hepatitis likely attributable to HEV infection: experience from a tertiary hospital in Bangladesh. J Health Pop Nutr 2008 (in press).

4. Mahtab MA, Rahman S, Khan M, Kamal M, Karim MF, Ahmed F, Hussain MF, Podder PK Aetiology of chronic hepatitis in Bangladesh. Indian J Gastroenterol 2007; 26 (Suppl 2): 142.

5. Afroz S, Mahtab MA, Rahman S, Khan M. Hepatitis B virus is the leading cause of cirrhosis of liver in Bangladesh. Hepatol Int 2007; 1 (1): 120 .

6. Khan M, Zaki KMJ, Ahmed KU et. al. Clinical profile: Prognostic index in hepatocellular carcinoma. Bangladesh Med Res Coun Bull 1991; XVII: 49-62.
7. Mahtab MA, Rahman S, Karim F. Clinical and histopathological characterization of asymptomatic hepatitis B virus positive subjects in Bangladesh. Acta Hep Japonica 2008; 49 (1):98.

8. Mahtab MA, Kumar S, Rahman S, Kamal M, Khan M, Aggarwal R. Genotypes of hepatitis B virus among chronically infected patients in a tertiary care hospital in Bangladesh. Indian J Gastroenterol 2006; 25: 219-21.

9. Hsu YS, Chien RN, Yeh CT et. al. Long-term outcome of spontaneous $\mathrm{HBeAg}$ seroconversion in patients with chronic hepatitis B. Hepatology 2002; 35: 1522-1527.

10. Mahtab MA, Rahman S. Correlation between HAI score and HBeAg in chronic hepatitis B. Digestive Dis \& Sci 2005; 50 (10):1993-1994.

11. Mahtab MA, Rahman S, Khan M, Mamun AA, Kamal M. Precore/core Promoter mutant hepatitis B virus produces more severe histologic liver disease than wild type hepatitis B virus. Hungarian Med J 2007; 1(1): 41-46.

12. Mahtab MA, Rahman S, Khan M, Mamun AA. HBeAg negative chronic hepatitis B with normal serum transaminase and low HBV DNA: what does it signify? Indian J Gastro 2007; 26: 297.

13. Kim TH, Kim YS, Yeom JJ, Cho EY, Kim HS, Kim HC, Park DS, Cho JH, Yoon GJ, Moon HB. Relevany between liver injury, serum $\mathrm{HBV}-\mathrm{DNA}$, and intrahepatic $\mathrm{HBcAg}$ in young male chronic $\mathrm{HBV}$ carriers. Korean J. Gastroenterol 2004; 44 (2): 84-91.

14. Yalchin K, Degertekin H, Nail ALP, Tekes S, Satichi O, Budak T. Determination of serum hepatitis B virus DNA in chronic HBsAg carriers: Clinical significance and correlation with serological markers. Turkish J Gastroenterol 2003; 14 (3): 157-163.

15. Thakeb F, El-Serafy M, Zakaria S, Monir B, Lashin S, Marzaban R, El-Awady M. Evaluation of liver tissue by polymerase chain reaction for hepatitis B virus in patients with negative viremia. World J Gastroenterol 2005; 11(43): 6853-6857.

16. Fan HM, Yang Z, Zhang CL, Li WL. Liver histopathological features of chronic HBV carriers and inactive HBsAg carriers. Zhonhua Gan Zang Bing Za Zhi 2007; 15(5): 334-337.

17. Dixit VK, Panda K, Babu AV, Kate MP, Mohapatra A, Vashistha P, Jain AK. Asymptomatic chronic hepatitis B virus infection in northern India 2007; 26(4): 159-161.

18. Arankalle VA, Chanda MS, Chobe LP. Five year follow up of HBsAg carriers. Indian J Gastroenterol 1999; 18 (Suppl): 27.

19. Sakhuja P, Malhotra V, Gondal R, Sarin SK, Guptan R, Thakur V. Histological spectrum of chronic hepatitis in precore mutants and wildtype hepatitis B virus infection. Trop Doct 2004; 34 (3): 147-149.

20. Papatheodoridis GV, Hadziyannis SJ. Diagnosis and management of pre-core mutant chronic hepatitis B. J Viral Hepatol 2001; 8: 311-21.

21. Chu CM, Liaw YF. Spontaneous relapse of hepatitis in inactive HBsAg carriers. Hep Int 2007; 1: 311-315.

22. Chu CJ, Hussain M, Lok ASF. Quantitative serum HBV DNA levels during different stages of chronic hepatitis B virus infection. Hepatology 2002; 36: 1408-1415.

23. Manesis EK, Papatheodoridis GV, Sevastianos V et. al. Significance of hepatitis B viremia levels determined by a quantitative polymerase chain reaction assay in patients with hepatitis $B$ e antigen negative chronic hepatitis B virus infection. Am J Gastroenterol 2003; 98: 2261-2267.

24. Tran T, Martin P. Chronic HBV without e antigen: using HBV DNA to guide management. Am J Gastroenterol 2003; 98: 2115-2117. 
25. Lok ASF, McMohan BJ. AASLD practice guideline: chronic hepatitis B. Hepatology 2007; 45(2): 507-539.

26. Lampertico P, Del Ninno E, Manzin A, Donato MF, Rumi MG, Lunghi $\mathrm{E}$ et. al. A randomized, controlled trial of a 24-month course of interferon alfa $2 \mathrm{~b}$ in patients with chronic hepatitis $\mathrm{B}$ who had hepatitis B virus DNA without hepatitis B e antigen in serum. Hepatology 1997; 26: 1621-1625.

27. Papatheodoridis GV, Manesis E, Hadziyannis SJ. The long-term outcome of interferon alfa treated an untreated patients with $\mathrm{HBeAg}$ negative chronic hepatitis B. J Hepatol 2001; 36: 306-313.

28. Lampertico P, Del Ninno E, Vigano M, Romeo R, Donato MF, Sablon E et. al. Long-term suppression of hepatitis B e antigen-negative chronic hepatitis by 24 -month interferon therapy. Hepatology 2003; 37: 756-763.

29. Manesis E, Hadziyannis SJ. Interferon alfa treatment and retreatment of hepatitis B e antigen-negative chronic hepatitis B. Gastroenterology 2001; 121: 101-109.

30. Santanatonio T, Mazzola M, Iacovazzi T, Miglietta A, Guastadisegni A, Pastore $G$ et. al. Long-term follow-up of patients with anti$\mathrm{HBe} / \mathrm{HBV}$ DNA-positive chronic hepatitis B treated for 12 months with lamivudine. J Hepatol 2000; 32: 300-306.

31. Lok AS, Hussain M, Cursano C, Margotti M, Garmenzi A, Grazi GL et. al. Evolution of hepatitis B virus polylerase gene mutations in hepatitis $\mathrm{B}$ virus e antigen-negative patients receiving lamivudine therapy. Hepatology 2000; 32: 1145-1153.

32. Papatheodoridis GV, Dirnou E, Dirnakopoulos K, Manolakopoulos S, Rapti I, Kitis G et. al. Outcome of hepatitis B e antigen-negative chronic hepatitis B on long-term nucloes(t)ide analog therapy starting with lamivudine. Hepatology 2005. 42: 121-129.
33. Hadziyannis SJ, Tassopoulos NC, Heathcote EJ, Chang TT, Kitis G, Rizzetto $\mathrm{M}$ et. al. Adefovir dipivoxil for the treatment of hepatitis B e antigen-negative chronic hepatitis B. N Eng J Med 2003; 348: 800-807.

34. Lai CL, Gane E, Liaw YF, Thongsawat S, Wang Y, Chen Y et. al.Telbivudine (LdT) Vs. Lamivudine for Chronic Hepatitis B: First-year results for the international phase III globe trial. Hepatology 2005; 42 (Suppl.): 748.

35. Papatheodoridis GV, Manolakopoulos S, Dusheiko G, Archimandritis AJ. Therapeutic strategies in the management of patients with chronic hepatitis B virus infection. Lancet Infect Dis. 2008; 8(3):167-78.

36. Keeffe EB, Zeuzem S, Koff RS, Dieterich DT, Esteban-Mur R, Gane EJ, Jacobson IM, Lim SG, Naoumov N, Marcellin P, Piratvisuth T, Zoulim F. Report of an international workshop: Roadmap for management of patients receiving oral therapy for chronic hepatitis B. Clin Gastroenterol Hepatol. 2007;5(8):890-7.

37. Sobaniec-Lotowska ME, Lebensztejn DM. Histological outcome of chronic hepatitis B in children treated with interferon alpha. World J Gastroenterol 2005; 11:7179-82.

38. Xu, WM, Cui, CYT, Wang, L, et al. Efficacy and safety of lamivudine in late pregnancy for the prevention of mother-child transmission of hepatitis B: a multicentre, randomised, double-blind, placebo-controlled study (abstract). Hepatology 2004; 40 (11); 272.

39. van Zonneveld, M, van Nunen, AB, Niesters, HG, et al. Lamivudine treatment during pregnancy to prevent perinatal transmission of hepatitis B virus infection. J Viral Hepat 2003; 10:294. 


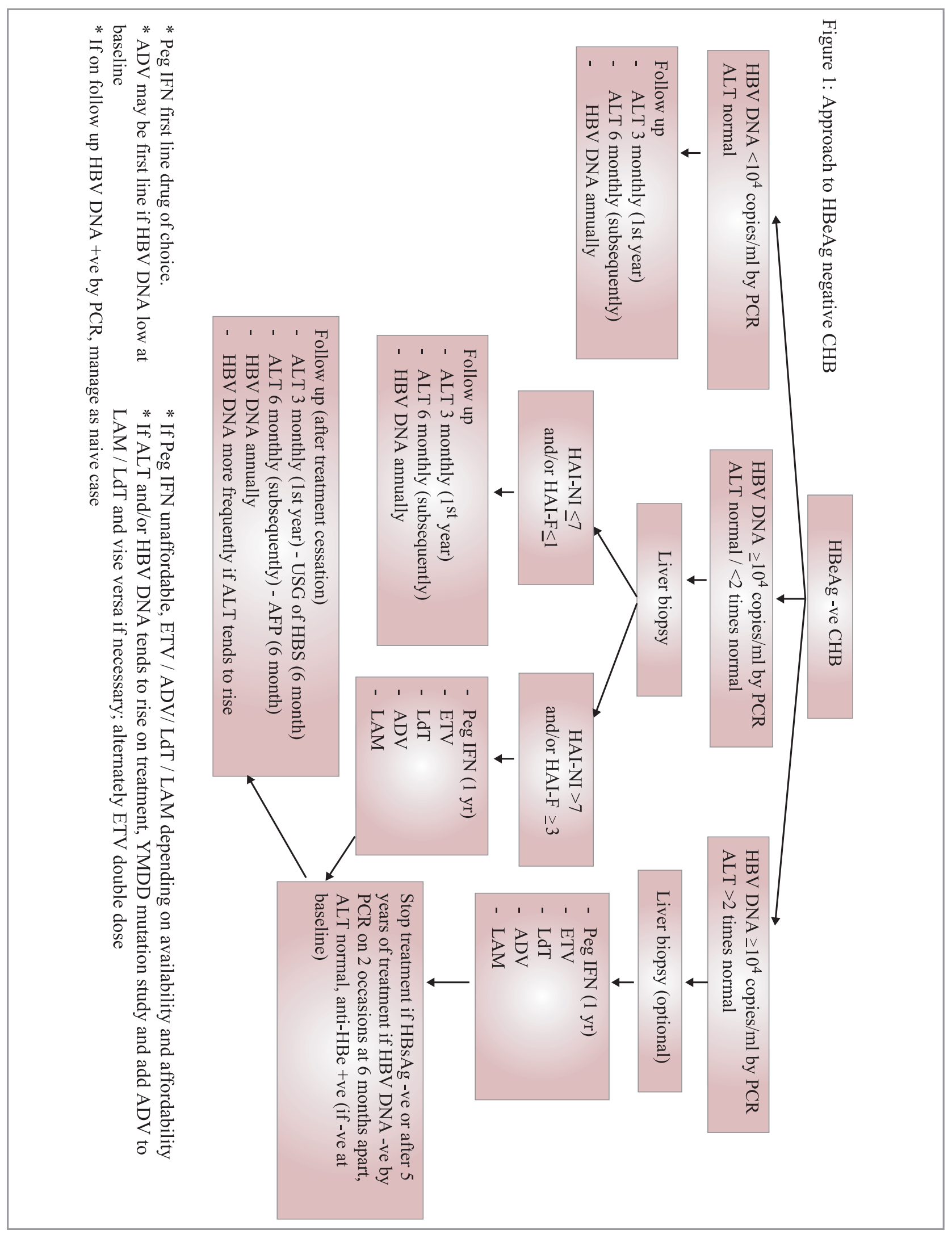




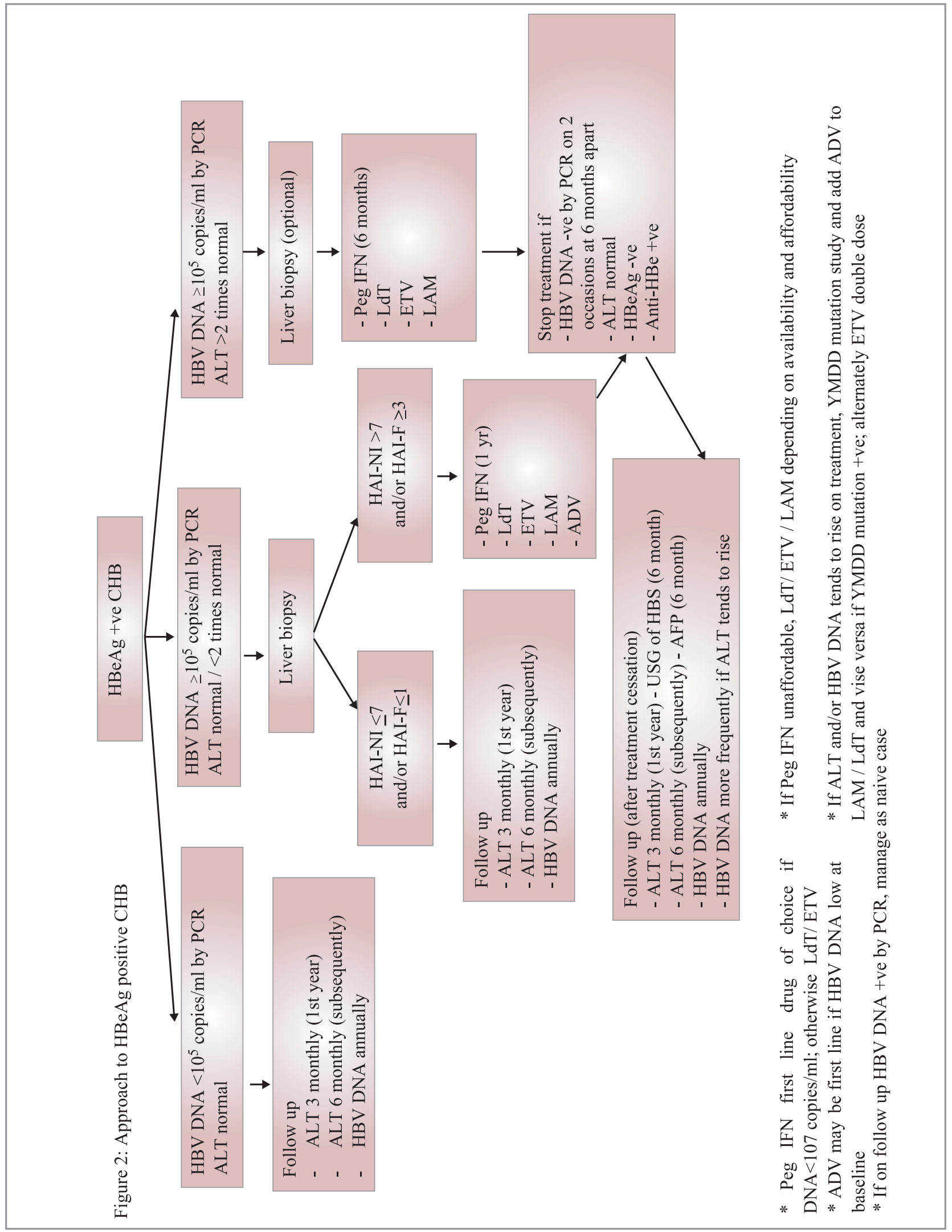

